\title{
EDITORIAL
}

\section{eLearning: mitos e distratores}

São várias as referências encontradas em textos contendo inúmeros mitos ligados ao modelo de educação à distância. Analogamente, é imenso o número de comentários ou opiniões sobre o assunto que servem como distratores para os interessados, afinal, são muitas, e fortes, as afirmações, algumas delas sem a devida sustentação, que visam confundir ou intimidar a decisão de se utilizar esse tipo de instrumento.

A pesquisa, nessa área, nos mostra que a intensidade dos mitos e dos distratores é inversamente proporcional ao tempo de existência efetiva de exemplos e relatos que, positiva ou negativamente, explicam esse fenômeno social e educacional. Em outras palavras, à medida que o tempo tem passado, tanto os mitos quantos os distratores têm diminuído. Exemplos de estabelecimentos que se aventuram nessa área, assim como exemplos de instituições que se organizam e avaliam cuidadosamente os diversos pontos relacionados à EaD para um adequado posicionamento não são poucos. E parte do processo de decisão relativo à adesão ou matrícula em um curso ou programa em EaD deve levar em conta esse fator.

O aspecto da qualidade não deveria ser um requisito apenas para os interessados em educação à distância, mas sim preocupação constante do modelo decisório dos interessados em qualquer tipo de apoio ao seu processo educacional. E, obviamente, somente essa preocupação não garante o êxito da experiência. Uma parcela importante da responsabilidade pelo sucesso do processo repousa nos ombros do aluno interessado (ainda mais em estágios avançados de estudos). A aproximação da entidade que claramente se mostra preocupada e consciente desses fatores é um grande passo na direção do sucesso.

No caso específico do elearning, um conceito fundamental a ser considerado envolve o fato de que não há sentido algum em se valer de um formato educacional alternativo para obter um resultado final inferior ao que se poderia obter no formato tradicional. Os esforços dos envolvidos nesse processo educacional devem ser comparados com os benefícios obtidos pelos participantes. Não há lógica no argumento de se "modificar" um processo educacional apenas por modificálo. Os expressivos números relacionados à educação, em termos, por exemplo, de egressos do ensino médio, em nossa sociedade clamam por processos educacionais alternativos: não há mistério nisso. Nesse ponto, a realidade brasileira se apresenta com desafios gigantescos, tanto em termos de volume de estudantes a serem capacitados, como em termos do tamanho de sua área geográfica. Pode-se observar, por exemplo, a área de contabilidade, na qual há aproximadamente 400 mil profissionais, número semelhante ao de profissionais nos EUA, para atuar em uma economia menor e com um volume de "provedores educacionais" (por exemplo, escolas e instituições) também menor. Ratifica-se, assim, o entendimento da importância de se terem modelos alternativos de educação profissional que atendam a um público e a uma realidade como a nossa.

Dois pontos são de extrema relevância ao se discutir eLearning e os vários mitos e distratores existentes: tempo e qualidade.

Em relação a tempo, o aluno interessado deve ter consciência de que o eLearning não "cria" tempo em sua agenda para estudos complementares. Isso significa dizer que, se o indivíduo não se organizar para fazer suas leituras, exercícios, trabalhos, atividades em grupos, apresentações, entre outras tarefas, o aprendizado não acontecerá, independentemente do formato utilizado: tradicional ou eLearning. Essa constatação, algumas vezes, é mal interpretada com afirmações de que o "elearning demanda mais estudo (ou mais tempo de estudo?) por parte do aluno". É válido assumir que o nível de dedicação aumenta no eLearning em razão da maior intensidade e personalização do aprendizado (amplia-se o tempo de dedicação e também a intensidade do resultado final).

Em relação à qualidade, como já mencionado, não se imagina que possa haver deterioração dos resultados do processo educacional. O que se espera é que os envolvidos (por exemplo, instrutores e alunos) se dediquem ao ambiente de elearning conforme o planejado e conforme suas necessidades individuais. O senso de responsabilidade pelo próprio aprendizado que o aluno de um ambiente de educação on-line deve possuir, reflete seu estágio de maturidade e percepção do valor que tal solução traz para sua situação específica e demanda real, naquele momento de sua carreira. Quantos exemplos poderiam ser dados de alunos de ambientes tradicionais que não "aproveitaram" as oportunidades que tal processo educacional oferece? Raciocínio semelhante pode ser feito em relação aos provedores e às oportunidades desperdiçadas dentro de um ambiente tradicional. A essência, nesse caso, é simples (como nas organizações): o equilíbrio entre interesses e forças (recursos) deve existir para que o processo possa integrar de forma efetiva os seus participantes. 
Enfim, o processo educacional com apoio de tecnologias mais avançadas, com o qual se depara na área educação para negócios (ou educação executiva) deve ser foco de atenção de instituições de ensino, de pesquisa, organizações, professores, pesquisadores, profissionais, consultores, alunos dos mais diversos estágios e demais envolvidos. Somente isso poderá garantir as condições mínimas de desenvolvimento dessa área, possibilitando o encontro de soluções que atendam os vários agentes do mercado, sempre considerando-se a ótica dos interessados.

EDGARD B. CORNACHIONE JR.

Professor Associado do Departamento de Contabilidade e Atuária da FEA/USP.

Realiza pesquisas sobre Business Education junto à

University of Illinois (Urbana-Champaign, IL, USA), onde participa de programa de doutorado (College of Education, Department of Human Resourse Education). 